Jurnal

Belo
Volume 6 Nomor 2 Februari 2021 - Juli 2021

DOI: https://doi.org/10.30598/belovol6issue2page148-156

p-ISSN : 2460-6820 | e-ISSN : 2686-5920

Penerbit : Fakultas Hukum Universitas Pattimura

\title{
Kajian Kriminologis Perbandingan Kejahatan Yang Terjadi Sebelum Pandemi Dan Saat Pandemi Covid-19
}

\section{Sigit Somadiyono, ${ }^{1, *}$}

${ }^{1}$ Fakultas Hukum Universitas Batanghari, Jambi sigit.somadiyono@unbari.ac.id $^{1}$

* Corespondence Author

\begin{abstract}
Abstrak
Coronavirus Disease (Covid-19) bukan saja memukul ekonomi bangsa namun juga menibulkan efek domino terhadap kejahatan yang naik pada saat pandemic. Tujuan penulisan ini untuk menemukan faktor yang mempengaruhi terjadinya kejahatan selama pandemi. Metode yuridis empiris, Teori Kriminologi dalam tulisan ini membantu mengambarkan faktor apa yang menjadi faktor dominan yang mengakibatkan naiknya kejahatan pada saat awal pandemi Covid-19 muncul di Indonesia, dari hasil penelitian disimpulkan ada beberapa faktor yang mempengaruhi seperti keluarga, ekonomi, dan kepribadian atau kejiwaan seseorang, semua ini karena pukulan atau efek dari Pandemi Covid1-19 diluar sektor kesahatan.
\end{abstract}

\section{Kata Kunci : Covid-19, Kriminologis, Kejahatan}

Naskah dikirim: 17 Januari 20201Direvisi: 10 Februari 2021|Diterbitkan: 27 Februari 2021

\begin{abstract}
Coronavirus Disease (Covid-19) not only hits the nation's economy but also has a domino effect on crime that increases during a pandemic. The purpose of this paper is to find the factors that influence the occurrence of crime during a pandemic. The empirical juridical


method, Criminology Theory in this paper helps describe what factors were the dominant factors that caused the increase in crime at the beginning of the Covid-19 pandemic that appeared in Indonesia, from the results of the study it was concluded that there were several influencing factors such as family, economy, and personality or psychology. someone, all of this is due to the beatings or the effects of the Covid1-19 Pandemic outside the health sector.

\section{Keywords: Covid-19, Criminology, Crime}

\section{Pendahuluan}

Suatu virus yang disebut sebagai 2019 novel coronavirus (2019-nCoV) menyebar dari Kota Wuhan Republik Rakyat Cina, dan kemudian WHO mengumumkan nama baru pada 11 Februari 2020 yaitu Coronavirus Disease (COVID-19) ${ }^{1}$, Presiden kemudian mengeluarkan status darurat melalui Keputusan Presiden Nomor 7 Tahun 2020, 31 Maret 2020 tentang Kedauratan Covid-19, ${ }^{2}$ dalam keputusan presiden ini, mengatakan bahwa Negara Indonesia sendang mengalami bencana Non-Alam yaitu Covid-19. Keadaan Darurat. ${ }^{3}$ Virus ini bukan saja menyerang manusia namun mempunyai efek domino keberbagai kehidupan masyarakat dan memukul perekonomian negara, dari sisi kejahatan jumlah kejahatan meningkat pada massa pandemik, data Kepolisan Republik Indonesia menyebutkan bahwa ada kenaikan signifikan terhadap jumlah kejahatan yang terjadi sejak pemerintah mengugumkan bahwa Covid-19 telah masuk dan telah menginfeksi 3 (tiga) orang ibu dan anak-anak, kenaikan tersebut sebesar $7 \%$ (tujuh persen). ${ }^{4}$

\footnotetext{
${ }^{1}$ Adityo Susilo dkk (2020), Coronavirus Disease 2019: Tinjauan Literatur Terkini, Jurnal Penyakit Dalam Indonesia, Volume. 7, Nomor. 1, Maret 2020, Universitas Indonesia, hal. 45

2 Tresya, T. (2020). Sifat Melawan Hukum Materiil Dalam Perbuatan Pidana Penanganan Bencana Non-Alam Covid 19. JURNAL BELO, 6(1), 1-10. https://doi.org/10.30598/belovol6issue1page1-10, hal 2

${ }^{3}$ Erwin Ubwarin dkk (2021), Kekebalan Hukum Pidana Dalam Penanganan Bencana NonAlam Akibat SARS-COV-2, Junal De Jure, Volume 21 Nomor 1, Februari 2021, Badan Penelitian dan Pengembangan Hukum dan Hak Asasi Manusia, hal 15

4 https://mediaindonesia.com/megapolitan/314036/lima-bulan-pandemi-covid-19-kriminalitasnaik-7-persen, diakses 2 Febuari 2020
}

DOI: https://doi.org/10.30598/belovol6issue2page148-156 
Sahetapy mengatakan bahwa Kriminologi berusaha untuk memperoleh pengetahuan dan pengertian mengenai gejala sosial di bidang kejahatan yang terjadi di dalam masyarakat, atau dengan perkataan lain mengapa sampai terdakwa melakukan perbuatan jahatnya itu. ${ }^{5}$ Kriminologi lebih mengutamakan tindakan preventif oleh karena itu selalu mencari sebab-sebab timbulnya suatu kejahatan baik di bidang ekonomi, sosial, budaya, hukum serta faktor alamiah seseorang, dengan demikian dapat memberikan break through yang tepat serta hasil yang memuaskan. Kriminologi lebih banyak menyangkut masalah teori yang dapat mempengaruhi badan pembentuk undang-undang untuk menciptakan suatu undang-undang yang sesuai dengan rasa keadilan masyarakat serta mempengaruhi pula hakim di dalam menjatuhkan vonis kepada tertuduh. ${ }^{6}$

Dalam tulisan ini penulis ingin membahas isu hukum bagaimana perbandingan kejahatan yang muncul sebelum pandemik dan peningkatan kejahatan setelah pandemik dengan memakai pisau analisis teori kriminologi agar menemukan sebab musebab kejahatan tersebut. Metode yang dipakai adalah Yuridis Empiris dengan mengunakan data primer dan data sekunder dianalisis untuk menjawab Isu Hukum yang telah diangkat.

\section{Pembahasan}

Hukum pidana dan kriminologi secara tegas berhubungan langsung dengan pelaku kejahatan, hukuman dan perlakuannya. Perbuatan jahat itu perlu diambil tindakan preventif mapun represif dengan tujuan agar penjahat jera atau tidak mengulangi lagi perbuatannya. ${ }^{7}$ Itu berarti kriminologi harus dipakai sebagai ilmu bantu hukum pidana dalam penegakan hukum.

\footnotetext{
${ }^{5}$ J. Sahetapy, Parados Kriminologi, Rajawali, Jakarta, 2012, hal. 82.

${ }^{6}$ Benediktus Bosu, Sendi-sendi Kriminologi, Usaha Nasional, Surabaya, 1982, hal.15

${ }^{7}$ Romli Atmasasmita, Bunga Rampai Kriminologi, Rajawali Pers, Jakarta, 1984, hal. 26
} 
Tabel 1. Rekapitulasi Kejahatan Tahun 2017-2019

\begin{tabular}{cccc}
\hline Tahun & 2017 & 2018 & 2019 \\
\hline Jumlah & 336.652 & 294.281 & 269.324
\end{tabular}

Sumber : Badan Pusat Statistik Tahun 2020

Data tabel 1 ini menunjukan bahwa perkara kejahatan yang ada, tiga tahun terakhir mengalami penurunan, tentunya ini hal yang baik dalam penegakan hukum, dan masyarakat semakin patuh hukum.

Penulis juga mengumpulkan data dari beberapa media tentang tingkat kejahatan yang naik signifikan pada saat awal pandemi di umumkan, yang dikemukakan oleh Humas Polisi Republik Indonesia, Kombes Pol Ahmad Ramadhan.

Tabel 2. Rekapitulasi Jumlah Kenaikan Kejahatan Pada Saat Awal Pandemi Covid19 di Indonesia Tahun 2020.

\begin{tabular}{cccccccc}
\hline Pekan & 19 & 20 & 21 & 22 & 23 & 24 & Total \\
\hline Jumlah & 3.481 & 3.726 & 2.726 & 3.177 & 4.244 & 5.876 & 23.230
\end{tabular}

Sumber : Humas Polri

Dari data di atas ditemukan bahwa kenaikan jumlah kejahatan naik signifikan sampai mencapai 23.230 (dua puluh tiga ribu duratus tiga puluh) kasus dalam 6 Pekan kenaikan. Bahkan jika diperhatikan terjadi 38, 45 \% jumlah kejahatan dalam sepekan di pekan ke 24, pendapat dari Ketua Departemen Kriminologi, Fakultas Ilmu Sosial dan Ilmu Politik Universitas Indonesia (FISIP UI), Iqrak Sulhin, beliau berpendapat, kejahatan terkait harta benda atau kejahatan properti (property related crimes), seperti pencurian dan perampokan, berpotensi naik lagi dengan asumsi situasi kesulitan ekonomi merupakan 
kondisi kriminogenik. Faktor kriminogen adalah faktor yang menyebabkan munculnya tindak pidana. kejahatan yang terjadi banyak adalah kejahatan jalanan (street crime).

Dari total data populasi sebanyak 23.230 kasus, penulis mengambil data 2.400 kasus, mengambil data statistik kriminal dari laporan tiap Polres dan Polresta serta data Polda dari Pekan ke-19 sampai dengan pekan 24 di Tahun 2, untuk mengetahui apa alas an mereka melakukan kejahatan pada pada saat pandemi Covid-19.

Meneliti suatu kejahatan harus memahami tingkah laku manusia baik dengan pendekatan deskriptif maupun dengan pendekatan kausa, sebenarnya dewasa ini tidak lagi dilakukan penyelidikan sebab musabab kejahatan, karena sampai saat ini belum dapat ditentukan faktor penyebab pembawa resiko yang lebih besar atau lebih kecil dalam menyebabkan orang tertentu melakukan kejahatan, dengan melihat betapa kompleksnya perilaku manusia baik individu secara berkelompok. ${ }^{8}$ Penulis memakai beberapa teori untuk melakukan pengkajian untuk dapat menjelasakan kenapa sampai kejahatan itu terjadi.

Teori sosialis mulai berkembang pada tahun 1850 M. Para tokoh alirn ini banyak dipengaruhi oleh tulisan Marx dan Engels, yang lebih menekankan pada determinasi ekonomi. Menurut para tokoh ajaran ini, kejahatan timbul disebabkan oleh adanya tekanan ekonomi yang tidak seimbang dalam masyarakat. A.S. Alam (kuliah kriminologi) memberikan pandangannya bahwa terjadinya kejahatan itu disebabkan oleh adanya faktor ketidakadilan sosial dalam masyarakat karena ekonomi masyarakat yang sudah sehingga terjadi kejahatan. ${ }^{9}$

Teori Kartografi/Geografi ajaran teori ini adalah distribusi kejahatan dalam daerahdaera tertentu, baik secara geografis maupun secara sosial. Para tokoh aliran ini antara lain Quetet dan Queery. Aliran ini dikembangkan di Prancis dan menyebar ke Inggris dan

\footnotetext{
${ }^{8}$ Made Darma Weda, Kriminologi. PT Raja Grafindo. Jakarta. 1996, hal 52

${ }^{9}$ Ibid 53
} 
Jerman. Aliran ini memerhatikan penyebaran kejehatan pada wilayah tertentu berdasarkan faktor geografik dan sosial. Aliran ini berpendapat bahwa kejahatan merupakan perwujudan dari kondisi-kondisi sosial yang ada. Aliran ini mengatakan bahwa kondisi geografis mempengaruhi seseorang untuk berbuat kejahatan. ${ }^{10}$

Teori tipologis, ada tiga kelompok yang termasuk dalam aliran ini, yaitu Lambrossin, Mental tester, dari psikiatrik yang mempunyai kesamaan pemikiran dan mitologi. Mereka mempunyai asumsi bahwa beda antara penjahat dan bukan pada penjahat terletak pada sifat tertentu pada kepribadian yang mengakibatkan seseorang tertentu berbuat kejahatan dan seseorang lain tadi kecenderungan berbuat kejahatan mungkin diturunkan dari orang tua atau merupakan ekspresi dari sifat-sifat kepribadian dan keadaan maupun proses-proses lain yang menyebabkan adanya potensi-potensi pada orang tersebut. ${ }^{11}$

\section{Tabel 3. Data Faktor Yang Menyebabkan Terjadinya Kejahatan Selama Pandemi Covid 19}

\begin{tabular}{ccc}
\hline Faktor & Jumlah Kasus & $\%$ (Persen) \\
\hline Faktor Lingkungan & 963 & 40,13 \\
\hline Faktor Ekonomi & 1331 & 55,46 \\
\hline Faktor Keluarga & 102 & 4,25 \\
\hline Faktor Geografis & 0 & 0 \\
\hline Faktor Kepribadian & 4 & 0,17 \\
\hline Jumlah & 2.400 & 100 \\
\hline
\end{tabular}

Sumber Data Statistik Kejahatan Pekan 19-24 Polda Se-Indonesia di Tahun 2020

\footnotetext{
10 Ibid 56 1996, hal 32

11 Dirdjosisworo Soejono, Kriminologi (Pencegahan Tentang Sebab-Sebab Kejahatan), Politeja.
} DOI: $\underline{\text { https://doi.org/10.30598/belovol6issue2page148-156 }}$ Copyright (c) 2021 Author 
Penerapan Saknsi Pidana diperlukan dalam kondisi pandemi Covid-19. ${ }^{12}$, namun harus memikirkan tentang faktor yang mempengaruhi kejahatan tersebut. Faktor lingkungan mencapai 963 Kasus atau $40.13 \%$ yang terjadi, manusia adalah makhluk sosial yang berinteraksi dengan manusia lain, faktor tenkanan lingkungan yang muncul membuat orang melakukan kejahatan, yang berikut adalah faktor ekonomi, faktor ini sangat dominan terhadap orang yang melakukan kejahatan, data yang diperoleh 30\% dari 1331 adalah bekas narapidana yang setalah keluar bedasarkan ketrampilan yang diperoleh dari pelatian di dalam Lembaga Pemasyarakatan yang diharapkan dapat digunakan setelah dia keluar, malah tidak bisa digunakan karena Pembatasan Sosial Berskala Besar, mantan warga binaan tersebut terpakasa harus berbuat kejahatan karena dia harus makan, ada juga karena kehilangan pekerjaan dia jadi melakukan kejahatan, faktor ekonomi ini juga berhubugan dengan faktor keluarga, umumnya kejahatan dilakukan oleh kepala keluarga atau tulang pungung keluarga yang kehilangan mata pencarian karena jika tidak anak dan istrinya mau makan apa, yang berikut adalah faktor kepribadian atau kejiwaan, kejahatan ini dilakukan karena memang orang tersebut mengalami ganguan kepribadian atau kejiawaan.

\section{Penutup}

Pandemi Covid-19 memukul bukan saja sektor Kesehatan namun juga sektor lainnya yang mengakibatkan tingkat kejahatan naik pada saat pandemi, hal ini berbeda dengan sebelum pandemi terjadi, dalam kajian kriminologis kami menumukan ada beberapa faktor yang mempengaruhi terjadinya kejahatan pada saat pandemi, yaitu faktor ekonomi, keluaraga, kepribadian atau kejiawaan. Ketiga faktor ini yang dominan mengakibatkan kejahatan terjadi.

${ }^{12}$ Yazid, F. (2020). Penerapan Sanksi Pidana Terhadap Pengambilan Paksa Jenasah Pasien Covid19 Di Indonesia. JURNAL BELO, 6(1), 60-72. https://doi.org/10.30598/belovol6issue1page60-72, hal 62

DOI: https://doi.org/10.30598/belovol6issue2page148-156 


\section{Daftar Pustaka}

Jurnal

[1] Susilo, A. (2020). Coronavirus Disease 2019: Tinjauan Literatur Terkini. Jurnal Penyakit Dalam Indonesia, Universitas Indonesia, 7 (1), Hal 45. DOI: https://doi.org/10.7454/jpdi.v7i1.415

[2] Tresya, T. (2020). Sifat Melawan Hukum Materiil Dalam Perbuatan Pidana Penanganan Bencana Non-Alam Covid 19. JURNAL BELO, 6(1), 1-10. DOI: https://doi.org/10.30598/belovol6issue1page1-10

[3] Ubwarin E dkk (2021), Kekebalan Hukum Pidana Dalam Penanganan Bencana NonAlam Akibat SARS-COV-2, Junal De Jure, 21 (1), Februari 2021, Badan Penelitian dan Pengembangan Hukum dan Hak Asasi Manusia. DOI: http://dx.doi.org/10.30641/dejure.2021.V21.13-22

[4] Yazid, F. (2020). Penerapan Sanksi Pidana Terhadap Pengambilan Paksa Jenasah Pasien Covid-19 Di Indonesia. JURNAL BELO, 6(1), 60-72. DOI: https://doi.org/10.30598/belovol6issue1page60-72

\section{Buku}

[5] Atmasasmita Romli, (1984) Bunga Rampai Kriminologi, Bandung, Rajawali Pers

[6] Benediktus B, (1982) Sendi-sendi Kriminologi, Surabaya, Usaha Nasional.

[7] Darma Weda Made, (1996) Kriminologi. Jakarta, PT Raja Grafindo. Jakarta.

[8] Dirdjosisworo Soejono, (1996) Kriminologi (Pencegahan Tentang Sebab-Sebab Kejahatan), Politeja.

[9] Sahetapy J. (2012) Parados Kriminologi, Jakarta, Rajawali 


\section{Lain-lain}

[10] https://mediaindonesia.com/megapolitan/314036/lima-bulan-pandemi-covid-19kriminalitas-naik-7-persen, diakses 2 Febuari 2020

DOI: https://doi.org/10.30598/belovol6issue2page148-156 